\title{
PENGARUH PENGHARGAAN DAN HUKUMAN TERHADAP MOTIVASI YANG BERDAPAK KEPADA KINERJA PENYALURAN KREDIT USAHA RAKYAT (KUR) MIKRO PADA PT. BANK RAKYAT INDONESIA (PERSERO) TbK KANTOR CABANG PURWAKARTA
}

\author{
Oleh : \\ Indra Herwinda \\ indrajayaperkasa99@gmail.com
}

\begin{abstract}
ABSTRAK
This research aim to know influence of reward $\left(X_{1}\right)$, punishment $\left(X_{2}\right)$, to motivation $(Y)$ and work performance $(Z)$. Population of this researchare all mantri at PT. Bank Rakyat Indonesia (Persero). Tbk Plant Office Purwakarta. 120 of mantri and sampel a number of 55 mantri. This research is including explanatory research. Analytical technique applied by pathanalysis. Independen variable in this research are reward and punishment, dependent variable is motivation and output variable is work performance. Based on result of research with hypothesis test obtained information that reward variable $\left(X_{1}\right)$ has significant effect to motivation $(Y)$ with value $\beta=0,308$. And $\rho$-value $=0,05$, punishment variable $\left(X_{2}\right)$ not has significant effect to motivation $(Y)$ because value $\beta=0,035$ and $\rho-$ value $=0,82$. Motivation variable $(Y)$ has significant effect to work performance $(Z)$ with value $\beta=0,370$ and $\rho-$ value $=0,01$. Based on result of analysed hence can be concluded that reward $\left(X_{1}\right)$ have significant effect to motivation ( $Y$ ) that impact to performance ( $Z$ ).
\end{abstract}

Key word: Reward, Punishment, Motivation and Work Performance 


\section{Pendahuluan}

Perbankan dalam sistem perekonomian nasional memiliki peran yang sangat penting dalam mewujudkan tujuan pembangunan nasional, yaitu mewujudkan kehidupan masyarakat yang adil, makmur secara lahir dan batin berdasarkan Pancasila dan Undang-undang Dasar Negara Republik Indonesia Tahun 1945. Perbankan merupakan pokok sistem keuangan Negara, karena perbankan merupakan salah satu sub sistem dalam sistem pembangunan nasional. Sebagai sub system pembangunan nasional, perbankan mempunyai peran yang sangat strategis karena bank salah satunya berfungsi untuk menghimpun dana dari masyarakat sebagai nasabah dalam bentuk simpanan dan menyalurkan kembali dana tersebut kepada masyarakat yang membutuhkan (Toswari, 2007). Bank diharapakan dapat menyerasikan, menyelaraskan, serta menyeimbangkan pemerataan hasil pembangunan nasional sehingga dapat meningkatkan pertumbuhan ekonomi, mendorong terciptanya stabilitas nasional sehingga pada akhirnya dapat mengarah pada peningkatan taraf hidup masyarakat secara keseluruhan. Pada umumnya kegiatan usaha bank adalah merupakan usaha yang berlandaskan pada kepercayaan masyarakat. Faktor yang sangat mempengaruhi keberhasilan bank dalam mencapai tujuannya adalah adanya tenaga kerja, pegawai atau karyawan. Tenaga kerja, pegawai atau karyawan sebagai makhluk sosial tidak dapat di samakan dengan faktor - faktor produksi lainnya, sebab tenaga kerja, pegawai atau karyawan termasuk karyawan bank memerlukan perhatian, kontrol, bimbingan dan motivasi dari pimpinan agar kinerjanya berprestasi serta dapat memberikan kontribusi yang positif bagi kemajuan perusahaan. Dalam hal ketenagakerjaan di dunia perbankan yang paling utama adalah tenaga kerja lapangan, karena tanpa adanya tenaga kerja lapangan bank tidak akan memiliki konsumen/nasabah. Salah satu pekerja lapangan dari bank adalah surveyor/CMO/mantri. Untuk tetap dapat bersaing dengan perbankan lainnya serta upaya pencapaian target yang telah ditetapkan oleh manajemen perusahaan, maka segenap pihak/stake holder harus dapat menunjukkan kinerja yang baik.

Pengertian kinerja menurut Simanjuntak (2005), "Kinerja adalah tingkat pencapaian hasil atas pelaksanaan tugas tertentu". Simanjuntak juga mengartikan kinerja individu sebagai tingkat pencapaian atau hasil kerja seseorang dari sasaran yang harus dicapai atau tugas yang harus dilaksanakan dalam kurun waktu tertentu. Surveyor/CMO (Credit Marketing Officer)/mantri merupakan ujung tombak dari berhasil atau tidaknya kesepakatan kredit antar calon nasabah dengan perusahaan pembiayaan/bank yang diharapkan menjadi kesepakatan ini berubah menjadi keuntungan pada kedua belah pihak. Adapun tugas CMO atau surveyor ini secara resminya adalah menilai layak atau tidak nnya nasabah untuk mengajukan permohonan kredit dan juga berhak menolak calon nasabah yang menurutnya bermasalah. Dengan system kerja targeting, para Surveyor/CMO (Credit Marketing Officer)/mantri tentunya akan sangat memaksimalisasikan waktu kerja agar tujuan bisa tercapai. Dan mengingat $\mathrm{CMO}$ ini sangat penting peranannya, maka pihak perbankan harus dapat memacu semangat para surveyor agar target penjualan bisa tercapai

33.

Buana Ilmu 
Berdasarkan amanat Keputusan Presiden Republik Indonesia Nomor 19 Tahun 2015 Tentang Komite Kebijakan Pembiayaan bagi Usaha Mikro, Kecil dan Menengah dan Peraturan Menteri Kordinator Bidang Perekonomian Republik Indonesia Selaku ketua komite Kebijakan Pembiayaan bagi Usaha Mikro, Kecil dan Menengah Nomor 188 Tahun 2015 Tentang Penetapan Penyalur KUR dan Perusahaan Penjamin KUR yang ditetapkan tanggal 30 Oktober 2015 telah menunjuk PT. Bank Rakyat Indonesia sebagai salah satu lembaga penyalur Kredit Usaha Rakyat (KUR). Secara nasional BRI mendapatkan jatah penyaluran KUR tahun 2016 sebesar Rp.67,5 Triliun. KUR adalah kredit/ pembiayaan yang diberikan oleh perbankan kepada Usaha produktif segmen Mikro, Kecil, Menengah dan Koperasi (UMKMK) yang Feasible tapi belum bankable. Tujuan program KUR adalah untuk meningkatkan akses pembiayaan dan mengembangkan UMKMK untuk penanggulangan/pengentasan kemiskinan dan perluasan kesempatan kerja (Keputusan Menteri Koordinator bidang Perekonomian Nomor : KEP22/M.Ekon/10/2009). Penyaluran KUR di BRI diatur di dalam Surat Keputusan Direksi Nomor Surat Edaran S.21b - DIR/ADK/08/2015 tanggal 18 Februari 2015 tentang Ketentuan Pelayanan Kredit Usaha Rakyat Mikro.

Agar Target penyaluran KUR 2016 dapat tercapai tepat waktu serta memiliki kualitas kredit yang bagus, maka dibutuhkan etos kerja yang tinggi sesuai yang diharapkan oleh perusahaan, khususnya BRI. Kinerja akan sesuai dengan harapan atau target apabila karyawan memiliki motivasi yang tinggi pula untuk mencapai target kinerja yang telah ditentukan.

Mathis (2009) mengemukakan bahwa, Motivasi (motivation) adalah keinginan dalam diri seseorang yang menyebabkan orang tersebut bertindak. Orang biasanya bertindak karena satu alasan : untuk mencapai tujuan. Jadi, motivasi adalah sebuah dorongan yang diatur oleh tujuan dan jarang muncul dalam kekosongan. Motivasi setiap orang berbeda-beda. Tergantung kepentingan dan kebutuhan individu tersebut. Salah satu faktor yang dapat menjadi pemicu motivasi seseorang adalah adanya suatu Penghargaan (reward).

Menurut Eni Nurmiyati (2008) Reward memiliki pengertian ganjaran, hadiah, penghargaan atau imbalan. Menurut Galih Dwi Koencoro, dkk (2013), reward yang diberikan kepada karyawan akan memberikan pengaruh yang signifikan terhadap kinerja. Dengan kata lain, reward yang diberikan kepada karyawan akan memotivasi karyawan untuk meningkatkan kinerja karyawan. Dapat disimpulkan bahwa, reward adalah feedback positif yang diberikan oleh perusahaan atas pencapaian yang telah dilakukan oleh karyawan

Penghargaan yang diberikan oleh BRI kepada karyawannya berbentuk Insentif (uang ) dan penghargaan yang tidak berbentuk uang. Penghargaan terhadap kinerja individu sesuai dengan pencapaian target masing - masing dengan kategori Istimewa, Sangat Baik, Baik, Cukup Baik dan Tidak Baik.

Selain penghargaan, faktor lain yang mempengaruhi motivasi individu adalah adanya suatu hukuman (punishment). Menurut Ivancevich et.al (2007:224), punishment adalah suatu konsekuensi yang tidak menyenangkan atau tidak diinginkan yang diberikan oleh atasan atas suatu perilaku tertentu yang telah dilakukan. Punishment (hukuman) jika digunakan secara efektif dapat menekan

34.

Buana Ilmu 
perilaku dalam organisasi, dengan kata lain punishment sebaiknya diberikan setelah melalui pertimbangan yang cermat dan objektif dari semua aspek yang relevan dengan situasi yang terjadi. Hukuman diberikan apabila ada aturan atau ketentuan yang dilanggar oleh pegawai baik itu secara sengaja ataupun tidak sengaja. Bentuk hukuman yang ada di BRI diterapkan secara berjenjang sesuai dengan kesalahan yang dilakukan. Hukuman tersebut adalah berupa teguran lisan, teguran tertulis, penurunan job grade dan pemutusan hubungan kerja.

Pada saat ini PT. Bank Rakyat Indonesia (Persero) Tbk. Kantor Cabang Purwakarta sedang mengalami masalah penurunan kinerja pegawai, hal ini dapat dilihat dari fenomena yang muncul yaitu pencapaian target Kredit Usaha Rakyat (KUR) yang merupakan program pemerintah dan menjadi andalan perusahaan, mengalami pergerakan yang fluktuatif yang dihasilkan oleh para mantri PT. Bank Rakyat Indonesia (Persero). Tbk Kantor Cabang Purwakarta. Mantri merasa seakanakan tidak mampu untuk mencapai semua target yang sudah ditetapkan. Sebaliknya ada juga Mantri yang merasa bersemangat dalam mencapai target yang telah ditetapkan. Mereka melaksanakan pekerjaan dengan tanpa mengeluh, sehingga hasilnya pun dapat lebih optimal. Mantri yang mempunyai semangat yang tinggi dalam menyelesaikan pekerjaannya itu adalah mantri yang mempunyai motivasi, untuk mendapatkan reward dari pihak perusahaan. Namun demikian dari hasil pencapaian kinerja mantri dalam hal penyaluran KUR mikro di BRI Purwakarta tidak sesuai dengan target yang ditentukan. Posisi Outstanding pinjaman KUR bulan Desember 2016 sebesar Rp. 124.526.923.739 dibandingkan targetnya yaitu Rp. 166.511.398.529,- hanya tercapai $74.79 \%$ yang secara angka adalah kurang Rp. 41.984.474.790 terhadapa target. Ini menjadi suatu indikasi penting bahwa ada masalah yang terjadi pada para mantri sehingga kinerja penyaluran KUR Mikro tidak mencapai target. Masalah tersebut harus segera diidentifikasi serta dicarikan solusi agar penyaluran KUR mikro di BRI Cabang Purwakarta dapat mencapai target yang ditentukan pada periode berikutnya tahun 2017.Perlu ada lecutan yang dapat memotivasi mantri agar mampu meningkatkan kinerja nya. Potret pencapaian kinerja 2016 memberikan gambaran jelas tentang motivasi mantri dalam penyaluran KUR Mikro. Apabila tidak dilakukan tindakan, maka ada kemungkinan target penyaluran KUR Mikro di tahun 2017 tidak akan tercapai. Padahal target di tahun 2017 yang dibebankan oleh pemerintah kepada BRI adalah 71 triliun. Hasli pencapaian yang tidak sesuai dengan target yang ditentukan ini karena mantri merasa kurangnya penghargaan dan hukuman yang menyebabkan lemahnya motivasi mantri dalam meningkatkan kinerja.

Berdasarkan uraian perumusan masalah di atas tujuan penelitian ini adalah:

1. Untuk mengetahui dan mengkaji penghargaan pada PT. Bank Rakyat Indonesia (Persero). Tbk Kantor Cabang Purwakarta.

2. Untuk mengetahui dan mengkaji hukuman pada PT. Bank Rakyat Indonesia (Persero). Tbk Kantor Cabang Purwakarta.

3. Untuk mengetahui dan mengkaji motivasi pada PT. Bank Rakyat Indonesia (Persero). Tbk Kantor Cabang Purwakarta.

4. Untuk mengetahui dan mengkaji kinerja pada PT. Bank Rakyat Indonesia (Persero). Tbk Kantor Cabang Purwakarta.

35.

Buana Ilmu 
5. Untuk mengetahui dan mengkaji korelasi antara penghargaan dan hukuman pada PT. Bank Rakyat Indonesia (Persero). Tbk Kantor Cabang Purwakarta.

6. Untuk mengetahui dan mengkaji pengaruh parsial penghargaan dan hukuman terhadap motivasi pada PT. Bank Rakyat Indonesia (Persero). Tbk Kantor Cabang Purwakarta.

7. Untuk mengetahui dan mengkaji pengaruh secara simultan penghargaan dan hukuman tergadap motivasi pada PT. Bank Rakyat Indonesia (Persero). Tbk Kantor Cabang Purwakarta.

8. Untuk mengetahui dan mengkaji seberapa besar pengaruh penghargaan,hukuman dan motivasi terhadap kinerja penyalurkan KUR mikro pada PT. Bank Rakyat Indonesia (Persero). Tbk Kantor Cabang Purwakarta.

9. Untuk mengetahui dan mengkaji peran motivasi sebagai mediasi antara penghargaan dan hukuman tergadap kinerja pada PT. Bank Rakyat Indonesia (Persero). Tbk Kantor Cabang Purwakarta

\section{Landasan Teori}

\section{2,1 Penghargaan}

Menurut Eni Nurmiyati (2008) Reward memiliki pengertian ganjaran, hadiah, penghargaan atau imbalan. Menurut Galih Dwi Koencoro, dkk (2013), penghargaan yang diberikan kepada karyawan akan memberikan pengaruh yang signifikan terhadap kinerja. Dengan kata lain, reward yang diberikan kepada karyawan akan memotivasi karyawan untuk meningkatkan kinerja karyawan. Dapat disimpulkan bahwa, reward adalah feedback positif yang diberikan oleh perusahaan atas pencapaian yang telah dilakukan oleh karyawan. Ivancevich et.al (2007:227) mengemukakan bahwa dalam mengembangkan dan mendistribusikan sebuah penghargaan diperlukan beberapa pertimbangan yaitu:

1) Penghargaan yang tersedia harus mencukupi kebutuhan dasar manusia. Kebutuhan dasar ini misalnya makanan, tempat tinggal dan pakaian.

2) Individu akan cenderung membandingkan penghargan yang diterimanya dengan penghargaan yang diterima oleh orang lain. Proses pembandingan ini merupakan upaya individu dalam mempersepsikan keadilan dalam perolehan penghargaan.

3). Proses dimana penghargaan didistribusikan seharusnya dipersepsikan sebagai proses yang adil. Hal ini akan meminimalkan persepsi bias dalam msistem penghargaan

4) Manajer yang mendistribusikan penghargaan harus memahami perbedaan setiap individu yang dibawahinya. Tujuannya agar penghargaan diberikan secara efektif.

Menurut Ivancevich et.al (2007) reward dapat diklasifikasikan kedalam dua kategori utama yaitu Reward instrinsik dan Reward ekstrinsik. Baik reward intrinsik maupun reward ekstinsik, keduanya memiliki tujuan yang sama bagi perusahaan (Ivancevich et.al, 2007; Carrel et.al, 1995 dalam Gugup Kismono, 2010; Veithzal Rivai dan Ella Jauvani Sagala, 2009) yaitu:

1). Menarik orang yang memiliki kualifikasi untuk bergabung dengan organisasi.

2). Mempertahankan karyawan agar terus datang untuk bekerja

36.

Buana Ilmu 
3). Memberikan motivasi kepada karyawan untuk mencapai tingkat kinerja yang tinggi.

4). Kemudahan pengaturan administrasi dan aspek hukum

5). Bersaing dalam keunggulan kompetitif

6). Menjamin Keadilan internal dan eksternal dapat terwujud.

7). Penghargaan terhadap perilaku yang diinginkan perusahaan

Dapat penulis simpulkan bahwa, reward adalah feedback positif yang diberikan oleh perusahaan atas pencapaian yang telah dilakukan oleh karyawan.

\subsection{Hukuman}

Menurut Ivancevich et.al (2007:224), punishment adalah suatu konsekuensi yang tidak menyenangkan atau tidak diinginkan yang diberikan oleh atasan atas suatu perilaku tertentu yang telah dilakukan. Punishment (hukuman) jika digunakan secara efektif dapat menekan perilaku dalam organisasi, dengan kata lain punishment sebaiknya diberikan setelah melalui pertimbangan yang cermat dan objektif dari semua aspek yang relevan dengan situasi yang terjadi.

Hukuman dapat diberikan oleh manajer atau atasan berupa kritikan, penurunan jabatan, bahkan berupa pemutusan hubungan kerja. Menurut Eni Nurmiyati (2011) punishment akan diberikan karena adanya pelanggaran terhadap aturan yang berlaku. Dalam konteks perusahaan, punishment akan diberikan kepada karyawan yang lalai atau melakukan suatu kesalahan yang merugikan perusahaan. Hukuman ini dapat berupa teguran, surat peringatan, skorsing maupun penghentian pekerjaan serta dapat juga berupa pembatalan bonus di bulan terkait. Dengan kata lain punishment dapat membuat kesempatan bonus maupun promosi dibatalkan. Tujuan punishment ini adalah agar karyawan lebih giat dan berusaha semaksimal mungkin dalam pekerjaannya.

Menurut Malayu Hasibuan (2009) salah satu peran penting dari punishment adalah memelihara kedisiplinan karyawan. Semakin berat punishment akan membuat karyawan merasa takut untuk melanggar aturan perusahaan, serta akan membuat sikap dan perilaku indisipliner berkurang. Akan tetapi, punishment harus diterapkan berdasarkan pertimbangan logis, masuk akal, dan telah diinformasikan secara jelas kepada karyawan. Punishment seharusnya diterapkan tidak terlalu ringan maupun terlalu berat karena punishment bersifat mendidik dan menjadi alat motivasi untuk memelihara kedisiplinan dalam organisasi.

Menurut Anwar Prabu Mangkunegaran (2013:131) pelaksanaan sanksi / hukuman terhadap seorang pegawai yang melakukan pelanggaran yaitu dengan memberikan peringatan, harus segera, konsisten Dari pemaparan diatas, penulis berpendapat bahwa yang dimaksud dengan hukuman adalah suatu kondisi tidak menyenangkan yang diterima oleh individu maupun kelompok sebagai akibat dari suatu perbuatan yang melanggar aturan yang telah ditetapkan.

Dari pemaparan diatas, penulis berpendapat bahwa yang dimaksud dengan hukuman adalah suatu kondisi tidak menyenangkan yang diterima oleh individu maupun kelompok sebagai akibat dari suatu perbuatan yang melanggar aturan yang telah ditetapkan.

\section{3 . Pengertian Motivasi}

37.

Buana Ilmu 
Motivasi berasal dari kata Latin Movere yang berarti dorongan atau gerakan. Motivasi dapat diartikan sebagai kekuatan (energi) seseorang yang dapat menimbulkan tingkat persistensi dan antusiasmenya dalam melaksanakan suatu kegiatan, baik yang bersumber dari dalam diri individu itu sendiri (motivasii intrinsik) maupun dari luar individu (motivasi ekstrinsik). Seberapa kuat motivasi yang dimiliki individu akan banyak menentukan terhadap kualitas perilaku yang ditampilkannya, baik dalam konteks belajar, bekerja maupun dalam kehidupan lainnya.

Mathis (2009) mengemukakan bahwa, Motivasi (motivation) adalah keinginan dalam diri seseorang yang menyebabkan orang tersebut bertindak. Orang biasanya bertindak karena satu alasan : untuk mencapai tujuan. Jadi, motivasi adalah sebuah dorongan yang diatur oleh tujuan dan jarang muncull dalam kekosongan. Kata-kata kebutuhan, keinginan, hasrat dan dorongan, semuanya serupa dengan motif, yang merupakan asal dari kata motivasi. Memahami motivasi sangatlah penting karena kinerja, reaksi terhadap kompensasi, dan persoalan SDM yang lain dipengaruhi dan memengaruhii motivasi. Motivasi terbentuk dari sikap (attitude) karyawan dalam menghadapi situasi (situation) kerja di perusahaan. Motivasi merupakan kondisi atau energi yang menggerakkan diri karyawan yang terarah atau tertuju untuk mencapai tujuan organisasi perusahaan. Sikap mental karyawan yang pro dan positip terhadap situasi kerja itulah yang memperkuat motivasi kerjanya untuk mencapai kinerja maksimal.

Sikap mental karyawan haruslah memiliki sikap mental yang siap sedia secara psikofisik (sikap secara mental, fisik, situasi dan tujuan). Artinya karyawan dalam bekerja secara mental siap, fisik sehat, memahami situasi dan kondisii serta berusaha keras mencapai target kerja (tujuan utama organisasi). Salah satu aspek memanfaatkan karyawan ialah pemberian motivasi (daya perangsang) kepada karyawan, dengan istilah populer sekarang pemberian kegairahan bekerja kepada karyawan. Ini juga berarti bahwa setiap karyawan yang memberii kemungkinan bermanfaat ke dalam perusahaan. Usaha untuk merealisasikani kemungkinan tersebut ialah dengan jalan memberikan motivasi. Motivasi inii dimaksudkan untuk memberikan daya perangsang kepada karyawan yang bersangkutan agar karyawan tersebut bekerja dengan segala daya dan upayanya. Motivasi juga berkaitan erat dengan kebutuhan seseorang. Oleh karena itu seorang pemimpin dituntutut harus mengetahui kebutuhan para bawahannya. Menurut Nurjanah (2010) berikut adalah beberapa tujuan motivasi:

1. Meningkatkan moral dan kepuasan kerja.

2. Meningkatkan produktivitas kerja.

3. Mempertahankan kesetabilan kerja.

4. Meningkatkan disiplin kerja.

5. Mengefektifkan pengadaan karyawan

6. Menciptakan suasana dan hubungan kerja yang baik.

7. Meningkatkan loyalitas, kreativitas dan partisipasi.

8. Meningkatkan tingkat kesejahteraan karyawan.

9. Mempertinggi rasa tanggung jawab terhadap tugasnya.

10. Meningkatkan efisiensi penggunaan alat-alat dan bahan baku.

38.

Buana Ilmu 
Penulis berpendapat bahwa Motivasi adalah niat/keinginan dalam hati yang menggerakkan dan mengarahkan aktivitas seluruh organ tubuh kepada suatu tujuan

\section{2,4 Pengertian Kinerja}

Kinerja pada dasarnya merupakan hasil kerja secara kualitas dan kuantitas yang dicapai seorang karyawan dalam melaksanakan tugasnya sesuai tanggung jawab yang diberikan kepadanya. Menurut Mathis (2006:65) mengemukakan bahwa kinerja (performance) pada dasarnya adalah apa yang dilakukan atau tidak dilakukan oleh karyawan.Kinerja karyawan yang umum untuk kebanyakan pekerjaan meliputi elemen kuantitas dari hasil, kualitas dari hasil, ketepatan waktu dari hasil, kehadiran, kemampuan bekerja sama.

Mangkunegara (2005:22) menyatakan, “Kinerja pegawai (prestasi kerja) adalah hasil kerja secara kualitas dan kuantitas yang dicapai oleh seseorang pegawai dalam melaksanakan tugasnya sesuai dengan tanggung jawab yang diberikan kepadanya"

Menurut Simanjuntak (2005), "Kinerja adalah tingkat pencapaian hasil atas pelaksanaan tugas tertentu. Simanjuntak juga mengartikan kinerja individu sebagai tingkat pencapaian atau hasil kerja seseorang dari sasaran yang harus dicapai atau tugas yang harus dilaksanakan dalam kurun waktu tertentu". Berdasarkan beberapa pendapat tentang kinerja dapat disimpulkan bahwa Pengertian kinerja mengandung substansi pencapaian hasil kerja oleh seseorang. Dengan demikian bahwa kinerja merupakan cerminan hasil yang dicapai oleh seseorang atau sekelompok orang. Kinerja perorangan (individual performance) dengan kinerja lembaga (institutional performance) atau kinerja perusahaan (corporate performance) terdapat hubungan yang erat. Dengan perkataan lain bila kinerja karyawan (individual performance) baik maka kemungkinan besar kinerja perusahaan (corporate performance) juga baik.

kinerja adalah hasil kerja yang telah dicapai diperbandingkan dengan kualitas, kuantias dan periode waktu yang telah ditentukan sejak awal. Dalam penelitian ini dimensi kinerja yang dipakai adalah dimensi kuantitas kerja dan kualitas kerja.

\subsection{Kerangka Pemikiran}

\subsubsection{Pengaruh Penghargaan terhadap Motivasi}

Tujuan yang harus dicapai dalam pemberian reward adalah untuk lebih mengembangkan motivasi yang bersifat intrinsik dan ekstrinsik, dalam artian bahwa pegawai melakukan sesuatu perbuatan, maka perbuatan itu timbul dari kesadaran pegawai itu sendiri. Dan dengan reward itu juga, diharapkan dapat membangun suatu hubungan yang positif antara pimpinan dengan pegawainya. Pada dasarnya ada dua tipe reward yaitu social reward dan psychis reward. Yang termasuk dalam social reward adalah pujian dan pengakuan dari dalam dan luar organisasi. Sedangkan psycis reward datang dari self esteem (berkaitan dengan harga diri), self satisfaction (kepuasan diri) dan kebanggaan atas hasil yang dicapai. Social reward merupakan extrinsic reward yang diperoleh dari lingkungannya, seperti finansial, marerial dan piagam penghargaan. Sedangkan psychis reward adalah instrinsic reward yang datang dari dalam diri seseorang, seperti pujian, sanjunagan dan ucapan selamat yang dirasakan pegawai sebagai bentuk pengakuan terhadap dirinya dan mendatangkan kepuasan bagi diri sendiri (mahsun, 2006: 112).

39.

Buana Ilmu 


\subsubsection{Pengaruh Hukuman terhadap Motivasi}

Hukuman merupakan ancaman hukuman yang bertujuan untuk memperbaiki karyawan pelanggar, memelihara peraturan yang berlaku dan memberikan pelajaran kepada pelanggar (Mangkunegara, 2000: 130). Pada dasarnya tujuan pemberian hukuman adalah supaya pegawai yang melanggar merasa jera dan tidak akan mengulangi lagi. Dengan adanya punishment tersebut diharapkan mampu memotivasi para mantri untuk bekerja lebih baik lagi sehingga apa yang menjadi target perusahaan dan terrealisasikan.

\subsubsection{Pengaruh Simultan Penghargaan dan Hukuman terhadap Motivasi}

Reward dan punishment juga memberikan motivasi dari luar untuk berkarya. Pengukuran kinerja bertujuan memberikan dasar sistematik bagi manager untuk memberikan reward, misalnya kenaikan gaji, tunjangan dan promosi atau sistem punishment, misalnya pemutusan kerja, penundaan promosi dan teguran. Sistem manajemen kinerja modern diperlukan untuk mendukung sistem berdasarkan kinerja atau disebut juga pembayaran berorientasi hasil.

Organisasi yang berkinerja tinggi berusaha menciptakan sistem reward, insentif dan gaji yang memiliki hubungan yang jelas dengan knowledge, skill dan kontribusi individu terhadap kinerja organisasi (mahmudi, 2005: 16). Dengan kata lain, sistem reward dan punishment dapat digunakan sebagai motivasi bagi pegawai dalam mengukur tingkat kinerjanya. Pemberian reward dan punishment tidak dapat dilakukan tanpa alasan yang rasional. Oleh karena itu, organisasi harus memiliki mekanismen reward dan punishment yang jelas

\subsubsection{Terdapat pengaruh motivasi terhadap kinerja}

Motivasi kerja pegawai merupakan sebuah kunci terhadap keberhasilan tujuan pencapaian target perusahaan. Dengan upaya motivasi diharapkan dapat meningkatkan kinerja pegawai sehingga apa yang direncanakan akan menjadi sebuah kenyataan dan bisa berdampak kepada pencapaian hasil produksi perusahaan

\subsubsection{Terdapat pengaruh penghargaan dan hukuman terhadap kinerja pada PT. Bank Rakyat Indonesia (Persero)., Tbk Kantor Cabang Purwakarta.}

\section{Metode Penelitian}

Penelitian ini menggunakan penelitian deskriptif dengan pendekatan kuantitatif yaitu mengungkapkan pengaruh antar variabel dan dinyatakan dalam angka serta menjelaskannya dengan membandingkan dengan teori-teori yang telah ada dan menggunakan teknik analisis data yang sesuai dengan variabel dalam penelitian. Variabel yang diteliti yaitu reward dan punishment sebagai variabel independen/bebas $(\mathrm{x})$, variabel motivasi sebagai variabel penghubung (y) dan variabel kinerja sebagai variabel dependen/terikat (z).

Metode pengumpulan data menggunakan metode survey. Singarimbun (2011:3) menjelaskan bahwa penelitian dengan metode survey ini merupakan penelitian yang mengambil sampel dari suatu populasi dan menggunakan kuesioner sebagai alat pengumpulan data yang pokok. Kuesioner adalah alat pengumpul data yang dilakukan dengan cara memberi seperangkat pertanyaan atau pernyataan tertulis kepada responden untuk dijawabnya.

\subsection{Populasi dan Sample}

40.

Buana Ilmu 
Menurut Sugiyono (2013:80) populasi adalah wilayah generalisasi yang terdiri atas obyek/subyek yang mempunyai kualitas dan karakteristik tertentu yang ditetapkan oleh peneliti untuk dipelajari dan kemudian ditarik kesimpulannya. Jadi populasi bukan hanya orang, tetapi juga obyek dan benda-benda alam yang lain. Hal ini sejalan dengan pendapat Emory dalam Assegaf (2009) yang menyatakan populasi merupakan sekumpulan elemen yang dapat digunakan untuk beberapa kesimpulan. Dengan demikian populasi dalam penelitian ini adalah seluruh mantri yang bekerja di PT. Bank Rakyat Indonesia (Persero). Tbk Kantor Cabang Purwakarta yang berjumlah 120 orang.

Menurut Sugiyono (2013:81) menjelaskan sampel adalah bagian dari jumlah dan karakteristik yang dimiliki oleh populasi tersebut. Bila populasi besar, dan peneliti tidak mungkin mempelajari semua yang ada pada populasi, misalnya karena keterbatasan dana, tenaga, dan waktu, maka peneliti dapat menggunakan sampel yang diambil dari populasi itu. Sampel pada penelitian ini adalah mantri yang bekerja di PT. Bank Rakyat Indonesia (Persero). Tbk Kantor Cabang Purwakarta. Dalam melakukan penelitian hal pertama yang dilakukan adalah menentukan sampel dengan menggunakan rumus Slovin untuk menentukan jumlah sampel, dengan rumus:

$$
\begin{aligned}
& \mathrm{n}=\frac{\mathrm{N}}{1+\left(\mathrm{N} \mathrm{X} e^{2}\right)} \\
& \text { Dimana }: \mathrm{n} \quad=\text { ukuran sampel } \\
& \mathrm{N}=\text { ukuran populasi }=120 \text { orang } \\
& e^{2}=\text { standar deviasi }=10 \%=0,1
\end{aligned}
$$

Dari formulasi di atas maka dihitung jumlah sampel sebagai berikut:

$$
\mathrm{n}=\frac{\mathrm{N}}{1+\left(\mathrm{N} \mathrm{X} e^{2}\right)}=\frac{120}{1+(120 \times 0,01)}=54,54 \text { Orang }
$$

jadi sampel yang diambil adalah 55 orang (pembulatan) yang dianggap mewakili populasi yang ada.

\subsection{Teknik Pengumpulan Data}

Dalam pengumpulan data ini, peneliti melaksanakan riset secara langsung pada objek penelitian untuk mendapatkan data yang diperlukan guna melengkapi data yang dibutuhkan yaitu dengan cara wawancara, angket dan studi pustaka.

\subsection{Rancangan Analisis dan Uji Hipotesis}

\subsubsection{Rancangan Analisis}

Analisa Statistik Deskriptif yaitu suatu metode pengumpulan data untuk memperoleh bahan-bahan teoritis yang dapat dijadikan dasar bagi pengkajian masalah. Melalui penelitian ini, Penulis mempelajari buku-buku dan lainnya yang ada hubungannya dengan masalah yang dibahas baik secara langsung maupun tidak langsung. Teknik deskriptif memberikan informasi mengenai data yang dimiliki dan tidak bermaksud menguji hipotesa. Terdapat empat jenis skala yang dapat digunakan mengukur atribut, yaitu skala nominal, skala ordinal, skala interval dan skala ratio. Adapun langkah-langkahnya adalah sebagai berikut :

a. Analisis Tabulasi Frekwensi

b. Analisis Rentang Skala

\subsubsection{Uji Hipotesis}

41. 
Berdasarkan permasalahan-permasalahan ada, maka Penulis mencoba membuat hipotesis yang masih perlu diuji kebenarannya.

Hipotesis 1 : Terdapat korelasi reward dan punishment pada PT. Bank

Rakyat Indonesia (Persero)., Tbk Kantor Cabang Purwakarta

Hipotesis 2 : Terdapat pengaruh reward terhadap Motivasi pada

PT. Bank Rakyat Indonesia (persero)., Tbk kantor Cabang Purwakarta

Hipotesis 3 : Terdapat pengaruh punishment terhadap motivasi

Hipotesis 4 : Terdapat pengaruh reward terhadap kinerja pada

PT. Bank Rakyat Indonesia (persero)., Tbk kantor Cabang Purwakarta

Hipotesis 5 : Terdapat pengaruh punishment terhadap kinerja

Hipotesis 6 : Terdapat pengaruh secara simultan Reward dan Punishment ter-

hadap motivasi pada PT. Bank Rakyat Indonesia (Persero)

Tbk. Kantor Cabang Purwakarta

Hipotesis 7 : Terdapat pengaruh motivasi terhadap kinerja Para Mantri

\section{Hasil Penelitian dan Pembahasan}

\subsection{Pengujian Instrumen}

1. Uji Validitas

Dari hasil pengujian data dengan menggunakan program SPSS pada semua variabel penelitian semua indikator yang tertuang dalam sebuah pernyataan pada kuesioner dinyatakan valid karena nilai validitas $>0,3$.

\section{Uji Realibilitas}

Berdasarkan hasil pengujian dapat disimpulkan bahwa semua variabel yang digunakan dalam penelitian ini adalah reliabel, karena memiliki nilai Cronbach Alpha $(\alpha)$ lebih besar dari 0,60. Sesuai yang disyaratkan oleh Ghozali (2005:42) bahwa suatu konstruk dikatakan reliabel jika nilai Cronbach Alpha> 0,60.

\section{Uji Normalitas}

Hasil perhitungan data menunjukkan variabel Penghargaan $\left(\mathrm{X}_{1}\right)=0.317$, Hukuman $\left(\mathrm{X}_{2}\right)=0.280$, Motivasi $(\mathrm{Y})=0.240$, Kinerja $(\mathrm{Z})=0.744$. Nilai p-value > 0,05 sehingga semua variabel mengikuti distribusi normal.

\subsection{Pembahasan Deskriptif}

Sugiyono (2008:142) mengatakan bahwa analisis deskriptif digunakan untuk menganalisis data yang telah terkumpul dengan cara mendeskripsikan atau menggambarkan obyek yang diteliti melalui sampel atau populasi sebagaimana adanya tanpa melakukan analisis dan membuat kesimpulan yang berlaku umum. Analisis deskriptif dalam penelitian ini meliputi : analisis statisitik deskriptif yang terdiri dari: nilai maksimal, minimal, mean, dan standar deviasi, serta kategorisasi jawaban responden. Adapun pembahasan mengenai masing-masing analisis deskriptif disajikan sebagai berikut :

1. Total skor dari hasil jawaban responden sebanyak 55 responden terhadap variabel penghargaan yaitu sebesar 2.692. dengan rata-rata sebesar 224 hal tersebut menandakan bahwa penghargaan berada pada kriteria sangat setuju karena berada pada rentang nilai 220 - 275. Artinya bahwa apa yang diharapkan oleh responden tentang adanya penghargaan sangat penting dan harus dilakukan oleh pihak perusahaan untuk meningkatkan semangat kerja khususnya mantri.

42.

Buana Ilmu 
2. Total skor variabel hukuman yaitu sebesar 2.697. dengan rata-rata sebesar 225 hal tersebut menandakan bahwa hukuman berada pada kriteria sangat setuju karena berada pada rentang nilai 220 - 275. Artinya bahwa apa yang diharapkan oleh responden tentang adanya hukuman sangat penting dan harus dilakukan oleh pihak perusahaan dengan tegas untuk meningkatkan semangat kerja khususnya mantri sehingga pada akhirnya para mantri akan jera atau tidak akan lagi mengulangi hal-hal yang bisa merugikan perusahaan.

3. Total skor dari hasil jawaban responden sebanyak 55 responden terhadap variabel motivasi yaitu sebesar 2.704. Dengan rata-rata sebesar 225 hal tersebut menandakan bahwa motivasi berada pada kriteria sangat setuju karena berada pada rentang nilai 220 - 275. Artinya bahwa apa yang diharapkan oleh responden tentang adanya dorongan dari perusahaan dalam melakukan kerja sangat penting dan harus dilakukan oleh pihak perusahaan untuk meningkatkan semangat kerja khususnya mantri.

4. Total skor dari hasil jawaban responden sebanyak 55 responden terhadap variabel kinerja yaitu sebesar 2.522. dengan rata-rata sebesar 210 hal tersebut menandakan bahwa kinerja berada pada kriteria setuju karena berada pada rentang nilai 165 - 220. Artinya bahwa apa yang diharapkan oleh responden tentang adanya penghargaan dan hukuman serta motivasi sangat penting adanya guna meningkatkan kinerja karyawan.

\subsubsection{Pembahasan Verifikatif}

1. Dari hasil analisis yang diperoleh didapat besaran koefesien korelasi antara variabel penghargaan dengan hukuman yaitu sebesar 0,561. Dengan demikian korelasi penghargaan dengan hukuman memiliki tingkat korelasi yang sedang dan nilainya positif dikarenakan berada di interval koefisien nilai $0,40-0,599$ : Korelasi sedang.

2. Pada alfa 5\%, pemberiaan penghargaan berpengaruh signifikan terhadap motivasi sebesar $21,66 \%$ dan tingkat signifikansi sebesar 0,05 dimana 0,05 lebih kecil dari 0,05. Hal ini berarti penghargaan berpengaruh signifikan terhadap motivasi kerja karyawan pada PT. Bank Rakyat Indonesia (Persero). Tbk Kantor Cabang Purwakarta. Hal tersebut sependapat dengan temuan Galih Dwi Koencoro, dkk (2013), dimana reward yang diberikan kepada karyawan akan memberikan pengaruh yang signifikan terhadap kinerja. Dengan kata lain, reward yang diberikan kepada karyawan akan memotivasi karyawan untuk meningkatkan kinerja.

3. Pada alfa 5\%, pemberian hukuman tidak berpengaruh secara signifikan terhadap motivasi mantrI dalam bekerja itu terlihat dari hasi lsignifikansi sebesar 0,18\% dan tingkat signifikan sebesar 0,82. Dimana 0,82 lebih besar dari 0,05. Hal ini berarti pemberian hukuman tidak berpengaruh signifikan terhadap motivasi pada PT. Bank Rakyat Indonesia (Persero).Tbk Kantor Cabang Purwakarta. Dengan adanya pemberian hukuman, ternyata membuat karyawan merasa tidak mendapatkan penghargaan atas upaya kerjanya untuk perusahaan, sehingga ketika diberikan hukuman terhadap mantri yang lalai menjalan tugas atau indispliner, para mantri malah semakin menurun motivasinya karena disebabkan oleh hukuman yang diterimanya.

43.

Buana Ilmu 
4. Dari hasil perhitungan didapatkan nilai pengaruh secara simultan sebesar 0,2184 atau $21,84 \%$. Artinya bahwa kontribusi variabel penghargaan dan hukuman terhadap motivasi serta kinerja karyawan sebesar 21,84\%, sedangkan sisanya sebesar 78,16\% dipengaruhi faktor lain yang tidak diteliti dalam penelitian ini.

5. Pada alfa 5\%, pemberian penghargaan berpengaruh terhadap kinerja sebesar $4,88 \%$ dan tingkat signifikansi sebesar 0,15 dimana 0,15 lebih besar dari 0,05. Hal ini berarti penghargaan berpengaruh tidak signifikan terhadap kinerja pada PT. Bank Rakyat Indonesia (Persero). Tbk Kantor Cabang Purwakarta. Pemberian hukuman berpengaruh terhadap kinerja sebesar 0,05\% dan tingkat signifikansi sebesar 0,88 dimana 0,88 lebih besar dari 0,05. Hal ini berarti hukuman berpengaruh tidak signifikan terhadap kinerja pada PT. Bank Rakyat Indonesia (Persero). Tbk Kantor Cabang Purwakarta

Sedangkan motivasi berpengaruh signifikan terhadap kinerja sebesar 0,1369 atau 13,69\% dan tingkat signifikansi sebesar 0,01 dimana 0,01 lebih kecil dari 0,05. Hal ini berarti motivasi berpengaruh signifikan terhadap peningkatan kinerja karyawan pada PT. Bank Rakyat Indonesia (Persero) Kantor Cabang Purwakarta. Motivasi berpengaruh positif terhadap peningkatan kinerja karyawan PT. Bank Rakyat Indonesia (Persero) Kantor Cabang Purwakarta. Berarti semakin tinggi motivasi karyawan atas suatu pekerjaan maka akan semakin meningkatkan kinerjanya. Demikian juga sebaliknya, semakin rendah motivasi karyawan kinerja yang diinginkan.

\section{Simpulan dan Saran}

\subsection{Simpulan}

1. Pelaksanaan pemberian penghargaaan kepada mantri pada PT. Bank Rakyat Indonesia (Persero )., Tbk Kantor Cabang Purwakarta sudah sangat baik. Namun kurangnya pemberian penghargaan akan mengakibatkan timbulnya semangat kerja yang kurang pula. Begitupun yang terjadi pada PT. Bank Rakyat Indonesia (Persero)., Tbk Cabang Purwakarta dimana pemberian penghargaan tersebut masih dirasa kurang diperhatikan. Itu terlihat dari adanya indikator dengan nilai terendah yaitu para mantr imerasa puas dengan bonus yang diberikan oleh pihak perusahaan dengan skor nilai 199.

2. Pelaksanaan pemberian hukuman pada PT. Bank Rakyat Indonesia (Persero)., Tbk Cabang Purwakarta sudah sangat baik. Namun masih terlihat adanya beberapa indikator yang memiliki nilai skor rendah, salah satu indikator terendah yaitu indikator setiap pelanggaran yang fatal merugikan perusahaan yang dilakukan oleh mantra langsung di PHK dengan skor nilai 199.

3. Motivasi pada PT. Bank Rakyat Indonesia (Persero)., Tbk Kantor Cabang Purwakarta sudah sangat baik. Namun demikian, didasarkan kepada temuan penelitian dimana terdapat tiga indikator yang memiliki nilai skor rendah. Dari ketiga indikator tersebut nilai terendah ada pada indikator saya tidak pernah mengeluh dalam melaksanakan pekerjaan dengan nilai skor 201.

4.Kinerja pada PT. Bank Rakyat Indonesia (Persero)., Tbk Kantor Cabang Purwakarta sudah baik, namun dari beberapa indikator terdapat dua indikator yang memiliki nilai skor rendah, namun indikator terendah ada pada Saya berusaha

44.

Buana Ilmu 
semampu saya untuk mencari calon debitur baru tanpa mengenal lelah dengan nilai skor 193 .

5. Besaran nilai koefesien korelasi antara variabel penghargaan dengan hukuman yaitu sebesar 0,561 Dengan demikian korelasi penghargaan dengan hukuman memiliki tingkat korelasi yang sedang dan nilainya positif dikarenakanberada di interval koefisien nilai 0,40 - 0,599 : Korelasi sedang (Sugiyono, 2014:184). Hal ini menunjukan bahwa penghargaan dan hukuman berperan dalam meningkatkan motivasi karyawan.

6. Besaran pengaruh penghargaan dan hukuman terhadap motivasi yang berampak kepada kinerja diperoleh masing-masing nilainya adalah 0,2166 atau 21,66\% untuk variabel penghargaan dan 0,0019 atau 0,19\% untuk variabel hukuman. Dari hasil yang diperoleh menunjukan bahwa penghargaan lebih dominan memberikan kontribusi terhadap motivasi karyawan dibandingkan pemberian hukuman $(0,2166>$ 0,0019).

7. Besaran pengaruh penghargaan dan hukuman terhadap motivasi sebesar 0,2184 atau $21,84 \%$. Artinya bahwa kontribusi variabel penghargaan dan hukuman terhadap motivasi sebesar $21,84 \%$, sedangkan sisanya sebesar 78,16\% dipengaruhi faktor lain yang tidak diteliti dalam penelitian ini. Dan berdasarkan hasil hipotesis yang diperoleh dapat disimpulkan bahwa penghargaan dan hukuman berkontribusi secara simultan dan signifikan terhadap motivasi yang berdampak kepada kinerja dapat diterima.

8. Besaran pengaruh penghargaan dan hukuman terhadap motivasi sebesar 0,2184 atau $21,84 \%$. Artinya bahwa kontribusi variabel penghargaan dan hukuman terhadap motivasi sebesar $21,84 \%$, sedangkan sisanya sebesar $78,16 \%$ dipengaruhi faktor lain yang tidak diteliti dalam penelitian ini. Dan berdasarkan hasil hipotesis yang diperoleh dapat disimpulkan bahwa penghargaan dan hukuman berkontribusi secara simultan dan signifikan terhadap motivasi yang berdampak kepada kinerja dapat diterima.

9.Motivasi berpengaruh signifikan terhadap kinerja sebesar 0,1369 atau 13,69\% . Motivasi menjadi salah faktor yang mempengaruhi hasil kinerja.

10.Pengaruh Penghargaan dan hukuman secara langsung kepada kinerja lebih kecil pengaruhnya dibandingkan pengaruh Penghargaan dan hukuman terhadap motivasi yang berdampak kepada kinerja $(21,84 \%>4,93 \%)$

\subsection{Saran}

1. Pihak manajemen diharapka nmeningkatkan pemberian penghargaan bagi karyawan dalam upaya meningkatkan kinerja. Para mantri yang memperoleh atau mencapai target serta yang telah bekerja sesuai dengan SOP perusahaan, diberikan bonus yang lebih besar dari bonus yang ada saat ini. Karena bonus merupakan salah satu pemicu yang akan mampu memberikan semangat terhadap para mantra dalam meningkatkan kinerjanya. Selain itu juga pihak manajemen harus memilik istandar baku dalam upaya pemberian penghargaan terhadap para mantri agar tidak terjadi disharmonisasi dan demotivasi dalam lingkungan pekerjaan. Terutama dalam pemberian penghargaan yang tidak sesuai dengan hasil kinerja yang telah dicapainya. Pemberian bonus dalam bentuk tidak berup amateri yang dilaksanakan saat ini di PT. Bank Rakyat

45.

Buana Ilmu 
Indonesia (Persero). Tbk., Kantor Cabang Purwakarta hendaknya tetap dilanjutkan dan dipertahankan.

2. Pihak manajemen diharapkan dapat bersikap tegas dalam upaya memberikan sanksi atau hukuman kepada karyawan yang telah melakukan kesalahan dan merugikan perusahaan. Pemberian hukuman kepada karyawan yang fatal melakukan kesalahan dan merugikan baik secara financial atau tidak hendaknya menerapkan pemberlakuan PHK langsung agar memberikan efek jera kepada karyawan lainnya sehingga mereka akan berpikir dua kali jika akan melakukan hal-hal yang dapat merugikan perusahaan. Adapun upaya yang sudah dilakukan oleh pihak manajemen saat ini dalam memberikan hukuman secara adil kepada para mantra hendaknya tetap dipertahankan.

3. Pihak manajemen sebaiknya meningkatkan komunikasi dengan mantra baik secara langsung atau melalui Kepala Unit agar bias mendengar keluh dan kesah para mantra dalam melaksanakan pekerjaannya. Keluhan tersebut akan berdampak pada peningkatan motivasi jika didengarkan serta diberikan solusi oleh pihak manajemen.

4. Pihak manajemen sebaiknya memberika npengarahan secara intensif kepada para mantra dalam bekerja setiap harinya agar bias mencari debitur baru, hal itu bias dilakukan dengan cara pemberian workshop pemasaran kepada para mantri agar debitur setiap harinya bertambah. Pengawasan dan terutama evaluasi terhadap hasil pelaksanaan Rencana Marketing Bulanan (RMB) yang telah dibuat oleh mantri. RMB yang dibuat oleh mantra bukan hanya sekedar menggugurkan kewajiban saja, namun harus dilaksanakan dengan konsisten dan penuh rasa tanggungjawab. Para mantra sendiri hendaknya mencari debitur setiap hari harus lebih giat lagidi lakukan karena modal utama keberlangsungan PT. Bank Rakyat Indonesia (Persero)., Tbk adalah dari debitur atau nasabah baru. Sehingga dengan bertambahnya debitur atau nasabah baru, para mantra pun tetap akan bekerja di Bank BRI.

5. Dalam penelitian ini didapat bahwa faktor penghargaan dan hukuman berpengaruh sebesar 21,84\% terhadapmotivasi. Masih terdapat faktor lain yang lebih dominan mempengaruhi motivasi yaitu sebesar 78,16 \% yang masih dapat diteliti. Oleh karena itu disarankan agar dilakukan penelitan terhadap faktorfaktor lainnnya yang mungkin bias berpengaruh terhadap motivasipada PT. Bank Rakyat Indonesia (PERSERO), Tbk Kantor Cabang Purwakarta.

46. 